\title{
КВАЗИПРАВДОПОДОБНАЯ ОЦЕНКА ВРЕМЕНИ ПРИХОДА СВЕРХШИРОКОПОЛОСНОГО СИГНАЛА НЕИЗВЕСТНОЙ ФОРМЫ ПРИ ВОЗДЕЙСТВИИ УЗКОПОЛОСНЫХ ПОМЕХ
}

\author{
ТРИФОНОВ А. П. ${ }^{1}$ БЕСПАЛОВА М. Б. ${ }^{1}$, ТРИФОНОВ П. А. ${ }^{2}$, ГУЩИН И. В. ${ }^{2}$ \\ ${ }^{1}$ Воронежский государственный университет, \\ Россия, Воронеж, 394006, Университетская пл., д. 1 \\ ${ }^{2}$ Военный учебно-научный центтр военно-воздушных сил \\ «Военно-воздушная академия им. проф. Н.Е. Жуковского и Ю.А. Гагарина», \\ Россия, Воронеж, 394064, ул. Старых Большевиков, 54A
}

\begin{abstract}
Аннотация. Исследованы характеристики квазиправдоподобной оценки времени прихода сверхширокополосного сигнала неизвестной формы, принимаемого на фоне узкополосных помех с неизвестными параметрами и гауссовского белого шума
\end{abstract}

Ключевые слова: сверхширокополосная оценка; узкополосная помеха; характеристики оценок

В последние годы новым направлением в теории и технике радиоэлектронных систем является применение сверхширокополосных сигналов (СШПС) [1-3]. Спектр СШПС очень широк, поэтому его воздействие вызывает возбуждение практически всех возможных типов собственных колебаний исследуемой цели, что делает высокоинформативной наблюдаемую реакцию. Важной особенностью СШПС является отсутствие собственно несущей частоты и, как следствие, невозможность классического описания радиосигналов с помощью комплексной огибающей.

В [4] рассмотрена оценка времени прихода СШПС на фоне только гауссовского белого шума (ГБШ). В реальных условиях на вход приемника поступают не только смесь сигнала и белого шума, но и другие помеховые воздей- ствия. В [3] исследованы алгоритмы оценки времени прихода СШПС на фоне помех, в качестве моделей которых использован гауссовский узкополосный процесс (ГУП) [5]. При этом форма СШПС считалась априори известной. Однако в реальных условиях форма принимаемого сигнала может быть неизвестна, т.к. она меняется при отражении от объекта (радиолокация), при распространении в различных средах (навигация, связь), а при мониторинге форма сигнала всегда не известна.

В данной статье рассмотрена задача оценки времени прихода СШПС неизвестной формы на фоне ГУП и ГБШ. При этом характеристики ГУП также могут быть неизвестны.

Пусть на интервале времени $t \in[0, T]$ наблюдается реализация вида

* Работа выполнена при поддержке Российского научного фонда (№14-49-00079) 